\title{
CORRELATES OF POTABLE WATER DEMAND AMONG FARMING HOUSEHOLDS IN ABAK, NIGERIA
}

\author{
A. E. NSIKAK-ABASI AND INIMFON V. PATRICK
}

(Received 19 November, 2008; Revision Accepted 14 September , 2009)

\begin{abstract}
This study estimated the correlates of potable water demand among farming households through the use of crosssectional data collected from 100 households in Abak, Nigeria. Based on the fact that heterogeneity and homogeneity exist within and among the clans and also to ensure equal representation of people from all social strata and income groups, stratified random sampling technique was employed. The study utilized both exploratory statistical techniques and econometric procedure in data analysis. Findings revealed that except sex, marital and multiplicity of usage, all other regressants were significant determinants of potable water demand among farming households. The study recommends increase in water outlets provided by Akwa Ibom Water Company (AKWC) as a panacea for persistent water shortages.
\end{abstract}

KEYWORDS: Correlates, Demand, Water, Households.

\section{INTRODUCTION:}

Water is essential for the growth of crops and animals; for household water uses, including drinking, cooking and sanitation; as a critical input into industry; cultural purpose; and for its role in sustaining the earth's ecosystems. (Rosegrant et al 2002). Demand for water has been steadily increasing in virtually all sectors such as an agricultural and industrial development. Rosegrant et al (2002) noted that population and income growth are crucial determinants of water and food supply and demand. According to Shiklomanov (1999) and UNDP (2000) and Current total world withdrawal of water for domestic, industrial and agricultural consumption is $11 \mathrm{~km}^{3} / \mathrm{yr}$, and demand for water from all sectors is expected to increase to same $36 \mathrm{~km} / \mathrm{yr}$ by 2025 (;). The high demand for water is driving unsustainable practices and competition for water resources between sectors, communities, and nations (UNEP, 2002). Access by all people, at all time to safe and sufficient fresh water supply is a basic condition for economic well being and healthy life (Udoh and Etim 2004; 2007). Approximately 1.1 billion people lack access to safe drinking water (IMF, 2003; Francis, 2005). One billion people are without clean drinking water and 1.7 billion have inadequate sanitation facilities (Rosegrant, 2001). Water, the environment, and food production are closely interrelated at the local, regional and global levels. (Rosegrant et al 2002). There are no regions in the world not affected by water problems, though the magnitude of the problems vary across countries. As reported by Deelstra and Girardet (2000), lack of water is a major problem to many, if not all developing countries. Lemunyete (2003) posited that water is a problem for both human and livestock and according to IMF (2003) growing water shortages and water pollution in developing and developed countries alike have plunged the world into a water crisis. Water use across the globe emerges from agricultural, industrial, and domestic uses. Water consumption and use has however been greatly hampered by the increasing population brought about by the influx of people into peri-urban and urban areas. IFPRI (2002) reported that population and economic growth in developing countries creates intense competition and water among agriculture, industrial and household use. As Udoh and Etim, $(2004 ; 2007)$ emphasized, the demand for water is fast outpacing its availability for consumption and the supply of domestic water is seriously constrained by the rising population. Because of population and economic growth, household, industry and agriculture are increasing their water demands, while water sheds and irrigated land are deteriorating and ground surface water pollution is increasing (IFPRI, 2000). With an estimated population 139,090 people (NPC, 2006), Abak is saddled with the challenge and responsibility of bridging the demand and supply gap of potable water among its residents.

According to (Ingevall et al; 2003), as population increase and urbanization intensifies, the present mismanagement of water together with the effects of climate change on rainfall distribution pattern has caused many to warn that we will soon come to term with a global water crisis. But Akwa lbom State Water Company (AKWC) whose responsibility is to pump and distribute sufficient clean water to residents in the study area is seriously constrained due to its inability to meet the rising demand for domestic potable water which according to Udoh and Etim (2004), the erratic power supply has seriously affected its ability to pump and distribute sufficient water. Consequently, private boreholes are drilled and water is sold to individuals at costs higher than the unit rate charged by the AKWC. Despite the availability of private water vendors in the State, the demand for potable water is far outpacing its supply. This study therefore aims at estimating the correlates of potable water demand among farming households in Abak urban.

A. E. Nsikak-Abasi, Dept. of Agricultural Economics and Extension, Univ. of Uyo, P.M.B. 1017, Akwa Ibom State, Nigeria. Inimfon V. Patrick, Department of Agricultural Technology, College of Agriculture, Obio Akpa, Akwa Ibom State, Nigeria. 


\section{Conceptual Framework and Review of Literature}

The concept of demand emanates from the theory of consumer behaviour (i.e. the concept of utility). The utility concept stipulates that individual or households purchase commodities to maximize utility (satisfaction) subject to limited resources available (Adegeye and Dittoh, 1985). Implicitly, the demand function is of the form $Q_{d}=F\left(P_{1}, X_{2}, \ldots . . X_{n}, Y_{d}\right)$ where $Q d$ is the quantity of the commodity, $\mathrm{P}_{1}$ is the price of the commodity, $\mathrm{X}_{2, \ldots . .} \mathrm{X}_{\mathrm{n}}$ are other explanatory variables and $Y_{d}$ is consumer or household disposable income. The theory of demand therefore suggests an inverse relationship between the quantity demanded of a commodity and its own price. This relationship which is otherwise called a direct price effect indicates that an increase in the price of a commodity results in a decrease in quantity demanded provided all other factors remain constant.

The relationships existing between the quantity demanded of a commodity and the prices of other commodities may be positive, negative or zero and this phenomenon is referred to as cross-price effect. Thus, for substitutes, the relationship is expected to be positive. It is expected to be negative for complementary goods and zero for non-related commodities. Demand therefore implies the quantity of a commodity that a consumer is willing and able to purchase at a given price and at a particular period of time. On the other hand, the term water demand is often used inconsistently in the literature, sometimes referring to water withdrawal and other times to water consumption or depletion. In this study, however, water demand implies or connotes water from a source and used for human needs, some of which may be returned to the original source and reused downstream with changes in water quantity and quality (Gleick, 1998).

Studies conducted on domestic water demand/ consumption include Morgan and Simolen (1973), Guariso et al (1981), Hansen (1996). The results of these studies show that domestic consumption of water is generally price and income inelastic. With respect to consumption shifters, Danielson (1979); Chicoine et al (1986), Briscoe and Ferranti (1988) Udoh and Etim (2004; 2007) found household size, multiplicity, sources, season and household income as major demand/consumption shifters. Both single and simultaneous structural modeling approaches have been adopted in estimating water demand/consumption models. For instance, Chicoine et al (1986) through block rate pricing system estimated water demand using a simultaneous equation approach. This study however, utilized the single equation approach in estimating households' consumption for domestic potable water.

\section{METHODOLOGY}

\section{Study Area, Data Collection and Sampling Procedure}

The study was conducted in Abak Local Government Council of Akwa Ibom State, Nigeria. Abak comprises five (5) clans namely: - Midim, Otoro, Ediene, Afahaobong and Abak. Abak lies on the tropical rainforest belt with its dominant vegetation of green foliage. The predominant occupations of the people are farming and trading. Due to its proximity to Uyo, the capital city of the state, majority of civil servants working in the city reside in this area. The implication of this is increased demand and pressure on the environment, water and other resources available.

A survey conducted in 2007 using structured questionnaire provided the primary data for the analysis. Based on the fact that there is heterogeneity within the clans and homogeneity among the clans, stratified sampling technique was employed and to ensure that people from all the social strata and income levels and groups are adequately and equally represented in the study, stratified random sampling technique was employed to select the respondents. With a total of 100 households sampled, at least 20 households from each of the five clans in Abak were sampled. Each representation of the various kinds of residential housing status of households (one of residential housing status of households (one room apartment, two room apartment, bungalows and duplexes) in the sample, 20 households were purposively sampled.

\section{METHOD OF DATA ANALYSIS}

Exploratory statistics and multivariate regression analysis were used in analysing the data. The exploratory statistics entails the use descriptive statistical tools like tables, frequencies, and means. This was basically used to describe the socioeconomic variable.

Multivariate regression analysis was employed to examine the relationship between water demand and household socioeconomic variables. The regression model is specified implicitly as follows:

$\begin{array}{cl}Q=f\left(X_{1}, \ldots \ldots . . .\right. & \left.X_{n}, U_{t}\right) \\ \text { where } Q= & \text { Quantity of water demanded } \\ X_{1} \ldots . . X_{n}= & \text { Explanatory variables } \\ U_{t} \quad=\quad \text { Error term } \\ \quad \text { The equation above was expressed explicitly in }\end{array}$ four functional forms

where $Q=$ Quantity of water demanded in liters

$X_{1}=$ Age of respondent in years.

$X_{2}=$ Sex of respondent $(D=1$ if male, $O$ if female).

$X_{3}=$ Marital status ( $D=1$ if Married, $O$ if otherwise).

$\mathrm{X}_{4}=\quad$ Level of Education $(\mathrm{D}=1$ if Educated, $\mathrm{O}$ if otherwise).

$X_{5}=\quad$ Household size (people living under the same roof and eating from the same pot).

$\mathrm{X}_{5}=\quad$ Distance between homes and existing source of water in $\mathrm{km}$.

$\mathrm{X}_{6}=\quad$ Family income in naira.

$X_{7}=\quad$ Location (Rural $=1$, Urban $=0$ ).

$\mathrm{X}_{8}=\quad$ Multiplicity of Usage. $(\mathrm{D}=1$ for multiple usage, 0 for otherwise).

Based on the signs, magnitudes and numbers of statistically significant estimators, log-linear model produced parsimonious coefficients across the regressants. Thus it became the lead equation which explicitly describes the consumption function of domestic potable water in Abak. This is consistent with other previous studies on demand and consumption of potable water by (Frankel and Shouvanavirakul (1973); Howe (1982); Frederick, 1993; Hansen, 1996; Udoh and Etim, 2004; 2007). 
RESULTS AND DISCUSSION

\section{Exploratory Statistics}

Table 1 shows the descriptive statistic of the shifters that explain and specify the demand function for water by farming households.
The result in table 1 reveal the mean age of 34 years which is an indication that respondent were within the active working age. The table also reveals that the average number of years in school was 10 . It is also shown that the income level of the households was quite high compared to previous study by Udoh and Etim (2004).

Table I: Summary Statistics of Explanatory Variable in the Model

\begin{tabular}{|c|c|c|c|c|}
\hline Variable & Unit & Mean value & $\begin{array}{l}\text { Min. } \\
\text { value }\end{array}$ & $\begin{array}{l}\text { Max. } \\
\text { value }\end{array}$ \\
\hline Age & Years & 34 & 20 & 68 \\
\hline $\begin{array}{l}\text { Education } \\
\text { Households size }\end{array}$ & Years & 10 & 2 & 13 \\
\hline & - & 4 & 1 & 10 \\
\hline Distance & $\mathrm{Km}$ & 0.037 & 0.01 & 0.1 \\
\hline Family income & Naira & 20,530 & 8,980 & 41,390 \\
\hline
\end{tabular}

Source: Field Survey, 2007

\section{Econometric analysis:}

The estimated equation shows goodness of fit, which is an indication that the model is well specified such that the important demand shifters are included in it. The estimated equation reveals that except for sex, marital status and multiplicity of use, all other variables greatly and aptly contribute to the demand of water in Abak by farming households.

Table II: Estimated Demand Function for Water

\begin{tabular}{lccc}
\hline Variable & $\begin{array}{c}\text { Unstandardized } \\
\text { coefficient }\end{array}$ & $\begin{array}{c}\text { Standard } \\
\text { error }\end{array}$ & t-statistics \\
\hline Age & -0.078 & 0.018 & $-4.333^{* * *}$ \\
Sex & 0.182 & 0.464 & 0.392 \\
Marital status & 0.133 & 0.202 & 0.658 \\
& 0.115 & 0.045 & $2.556^{* *}$ \\
Education & 0.086 & 0.015 & $5.733^{* * *}$ \\
Household size & & & \\
& -0.019 & 0.006 & $-3.167^{* * *}$ \\
Distance & & & \\
Family income & 0.129 & 0.048 & $2.688^{* * *}$ \\
& -0.038 & 0.021 & $-1.810^{*}$ \\
Location & 0.023 & 0.038 & 0.605 \\
Multiplicity & 0.082 & 0.022 & $3.727^{* * *}$ \\
Intercept & & & \\
\hline
\end{tabular}

$R^{2}=0.661=R^{2}$ (Adj) 0.624, $F=15.862^{* * *}$

$* * *, * *,{ }^{*}$ indicate significance at $1 \%, 5 \%$ and $10 \%$ levels respectively.

Source: Field Survey, 2007.

The result implies that any change in any of these factors resulted in a change in water demand among the households. Positive relationship is established for household size, education, and family income. A negative relationship is established for age, distance to source of water and location. Results imply that farming households with large members consume more water (spend more) than those with fewer members and vice versa. Similarly, the higher the income level and educational status of the respondents, imply more spending on water consumed. On the other hand, the higher the age of the respondents, the lower the water demand. This implies that younger people demand more for water than older people. This is true because as people grow older, they expend less energy and consume less water whereas younger people who are very active in their youthful years require more water for consumption. Besides, urban households spends more on potable water than people residing in peri-urban and rural areas and this is depicted by the negative relationship obtained from the results. Findings are synonymous with Oluwatayo (2006). Results further reveal that 66.1 percent of the total variability in water demand among farming households in the study area is explained in the regression model as indicated by the coefficient of determination. The lower adjusted Rsquared of 0.624 implies that the inclusion of any 
additional variable may not necessarily improve the regression result.

\section{CONCLUSION}

This study has highlighted factors which affect the demand for potable water through a demand function. The estimated parameters which were unbiased, efficient and consistent was estimated using the multivariate regression model. The estimation of the demand function for water by farming households in Abak reveal that except for sex, marital status and multiplicity of use, all other explanatory variables significantly and aptly affect the demand for water by farming households in Abak. The study recommends increase in water outlets provided by Akwa Ibom Water Company (AKWC) as a panacea for persistent water shortages.

\section{REFERENCES}

Adegeye, A. J. and Dittoh , J. S., 1985. Essentials of Agricultural Economics. Impact Publishers.

Briscoe, J. and Ferranti, D., 1988. Water for Rural Communities: Helping People to help themselves. Washington, p. 32.

Chicione, D. L., Deller, S. C. and Ramamurthy, G., 1986. Water Demand Estimation Under Block Rate Pricing: A Simultaneous Equation Approach. Water Resource Research 22(6): 859-863.

Danielson, L., 1979. - An Analysis of Residential Demand for Water using Micro time series data. Water Resource Research 15:763-767.

Deelstra, T. and Girardet, H., 2000. - Urban Agriculture and Sustainable Cities. Nico Bakkar et al eds; Growing Cities, Growing Food. Urban Agriculture on the Policy Agenda.

Francis, J., 2005. - "Gender, Water and Energy" ENERGIA News. Newsletter of the Network of Gender and Sustainable Energy Vol. 18 No.1.

Frankel, R. J. and Shouvanavirakul, P., 1973. Water Consumption in Small Communities for Northern Thailand. Water Resource Research 9(5): 1196 $-1207$.

Frederick, K. O., 1993. Balancing Water Demand with Supplies: The Role of Management in a world on increasing Scarcity. World Bank, Washington.

Gleick, P. H., 1998. The world's water 1998-1999. The biennial report on freshwater resources. Washington D. C: Island Press.

Guariso, G., Mairment, D., Rinaldi, S. and SonoimiSessa, R., 1981. Supply and Demand Coordination in Water Resource Research 17(4): 778-782.
Hansen, L. G., 1996. Water and Energy Price Impacts on Residential Water Demand in Copenhagen, Land Economics 72(1): 66-79.

Howe, C. W., 1982. - The Impact of Price on Residential Water Demand. Some Insights. Water Resource Research 18(4): 713-716.

IFPRI (International Food Policy Research Institute)., 2000. The Life-Cycle of Malnutrition Eradicating Malnutrition: Income Growth or Nutrition Program? Annual Report: 36.

IMF (International Monetary Fund)., 2003. Plunging into Crisis" Inflation. Too high, too low or just right? Finance and Development. A quarterly Publication of the International Monetary Fund. Vol.40 No.2.

Ingevall, A., Van Campen, E., Minderhoud-Jones, M., Roem, W. and Willesmen, W. W., 2003. eds: Using Every drop of Water. Magazine of Low External Input and Sustainable Agriculture LEISA Vol.19 No.2.

Lemunyete, L., 2003. "Right and Resource" Magazine for Low External Input and Sustainable Agriculture LEISA Vol.19 N0.3.

Morgan, W. D. and Simolen, J. C., 1973. Climatic Indicators in the Estimation of Municipal Demand. Water Resource Research 2(4): 521 529.

NPC (National Population Commission)., 2006. Population Census of the Federal Republic of Nigeria Analytical report at the National Level, National Population Commission, Abuja.

Oluwatayo, I. B., 2006. Correlates of Water Demand Among Farming Households In Ekiti State Nigeria. Nigeria Journal of Rural Sociology Vol.6. Nos.18, No. 1\& 2 Pp 75-82.

Rosegrant, M. W., 2001. Dealing with Water Scarcity in the $21^{\text {st }}$ Century. Pinstrup Andersen and R. Pandya-Lorch (Eds). The Unfinished Agenda. International Food Policy Research Institute.

Rosegrant, M. W., Cia, X. and Cline, S. A., 2002. World Water and Food to 2025. Dealing with Scarcity. International Food Policy Research Institute and International Water Management Institute.

Shiklomanov, I. A., 1999. - World Water Resource: Modern Assessment and Outlook for the $21^{\text {st }}$ Century. Federal Service of Russia for Hydro meteorology and Environmental Monitoring, State Hydrological Institute, St. Petersburg.

Udoh, E. J. and Etim, N. A., 2007. - Analysis of Domestic Water Consumption Pattern by Farming Households in Itu, Akwa Ibom State, 
Nigeria. European Journal of Social Sciences 2 Pp 76-82.

Udoh, E. J. and Etim, N. A., 2004. - An Analysis of Dry Season Water Consumption Pattern of Households in Uyo Metropolis, Nigeria. Journal of Sustainable Tropical Agricultural Research. Vol.12 pp 14-19.
UNDP (United Nations Development Programme)., 2000. - Human Development Report Oxford University Press, New York.

UNEP (United Nations Environmental Programme)., 2002 - Africa Environmental Outlook. Past, Present and Future Perspectives.

WHO (World Health Organization) and United Nation Children Fund., (2000) Global Water Supply and Sanitation Assessment, 2000 report. Geneva, United Nation. 